\title{
Spatial and temporal distribution of cotton squares and small cotton bolls fallen on ground after damage by boll weevil and the efficiency of the equipment used to collect them
}

\author{
Carlos Alberto Domingues da Silva ${ }^{1^{*}, 2}$ Marília de Macêdo Freire Duarte ${ }^{2}$ \\ Suziane Gomes Gonçalves ${ }^{2}$ Eduardo Domingos Vasconcelos ${ }^{1}$
}

${ }^{1}$ Empresa Brasileira de Pesquisa Agropecuária (EMBRAPA), Centro Nacional de Pesquisa de Algodão, Rua Oswaldo Cruz, 1143, Centenário, 58428-095, Campina Grande, PB, Brasil. E-mail: carlos.domingues-silva@embrapa.br. "Corresponding author.

${ }^{2}$ Universidade Estadual da Paraíba (UEPB), Campina Grande, PB, Brasil.

ABSTRACT: In this study, we determined the spatial and temporal distribution of fallen cotton squares and small cotton bolls fallen damaged by boll weevil and the efficiency and time interval of the equipment used to collect cotton samples. Spatial and temporal distribution of cotton squares and small cotton bolls fallen on the soil damaged by boll weevil among cotton rows was determined in an experimental design of randomized blocks in a factorial arrangement of $4 x 3$, represented by soil surface tracks located at $1-11 \mathrm{~cm}, 12-22 \mathrm{~cm}, 23-33 \mathrm{~cm}$, and $34-44 \mathrm{~cm}$ away from the planting row of cotton plants 70, 85, and 100 days of age. Efficiency and collection time interval of the cotton samples fallen on the soil infested by boll weevil by plastic rakes that were straight or fan-shaped, big broom, collector instrument model CNPA and aspirator of leaves 'Trapp' were determined in randomized block design with five treatments, 10 repetitions for each. Results demonstrated that the collection of cotton samples must be performed with greater attention to soil strips located below the cotton top projection and aspirator 'Trapp' of leaves was more appropriate for the operation as it used less time of collection with similar efficiency to other available equipment.

Key words: Anthonomus grandis, Gossypium hirsutum, punctured squares by oviposition and feeding.

Distribuição espacial e temporal dos botões florais e pequenas maçãs de algodão caídas ao solo danificadas pelo bicudo e eficiência de equipamento para coletá-los

RESUMO: Neste estudo, determinou-se a distribuição espacial e temporal dos botões florais e pequenas maçãs de algodoeiros caídas ao solo danificadas pelo bicudo e a eficiência de equipamentos para coletá-las. A distribuição espacial e temporal dos botões florais e pequenas maçãs de algodoeiros caídas ao solo danificadas pelo bicudo entre as fileiras de algodão foram determinadas em delineamento experimental de blocos ao acaso em arranjo fatorial 4x3, representado por faixas de superficie de solo localizadas entre 1-11 cm; 12-22cm; 23-33cm e 34$44 \mathrm{~cm}$ de distância da fileira de plantio em algodoeiros com 70, 85 e 100 dias de idade. A eficiência de coleta dos botões florais e pequenas maçãs caídas ao solo danificado pelo bicudo pelos rastelos plásticos em leque e reto, vassourão, catador modelo CNPA e aspirador de folhas "Trapp" foi determinado em delineamento de blocos ao acaso com cinco tratamentos e 10 repetições. Os resultados demonstraram que a coleta dos botões florais e pequenas maçãs caídas ao solo devem ser realizadas com maior atenção nas faixas de solo localizada abaixo da projeção da copa do algodoeiro e que o aspirador "Trapp" se mostrou mais adequado para essa operação porque gastou menos tempo para coletar essas estruturas vegetais, embora tenha apresentado eficiencia semelhante aos demais equipamentos.

Palavras-chave: Anthonomus grandis, Gossypium hirsutum, botões florais com orificio de oviposição e alimentação.

\section{INTRODUCTION}

Cotton crop (Gossypium hirsutum L.) is attacked by a wide variety of phytophagous arthropods with potential to cause serious damage to culture (RIBEIRO et al., 2015). Among these, the boll weevil Anthonomus grandis Boheman (Coleoptera: Curculionidae) is a key pest of cotton in the new world (SALVADOR et al., 2014). This insect has spread throughout the cotton-producing regions of Brazil, which has led to a severe increase in the cost of production due to economic losses arising from the insect feeding behavior and oviposition on the cotton squares and bolls (SILVA \& RAMALHO, 2013).

The boll weevil is mainly controlled by application of chemical insecticide during the flowering period to protect cotton squares (SILVA \& RAMALHO, 2013; SILVA \& SILVA, 2015). Important alternatives to cotton insecticides include various types of cultural control tactics, as suggested elsewhere (GREENBERG et al., 2010).

The collection of cotton squares and cotton bolls damaged by weevil and fallen on the ground is one such tactic that promises to be of great value to 
reduce the population of the first generation of this pest when applied in the initial stage of flowering as well as delay and/or reduce the infestation of the crop by later generations (NEVES et al., 2013; 2014). Researchers have attempted to mechanize the collection of these fruiting structures infested by cotton boll weevil. COAD \& MCGEHEE (1917) built a machine to collect boll weevil adults and squares of infested cotton plants, but their attempts to control the boll weevil were unsuccessful. Efforts have been made to develop an experimental machine mounted on tractor (the flail type) to destroy the squares damaged by cotton boll weevil and fallen on the ground. This machine was tested under various conditions and demonstrated promising results in the control of boll weevil when applied in the initial period of formation of reproductive structures (BURT et al., 1969).

In Brazil, inspired by the beach paper collectors at the end of the 1990s, the agronomist José Eymard do Nascimento of EMATER-CE idealized a small collector of cotton squares fallen on the soil, which was further improved by Embrapa Cotton after several field studies (BELTRÃO et al., 1997). Despite functioning well, this collector was little used by small cotton producers, perhaps because the practice of collecting and destroying cotton squares fallen on the soil was little known by cotton farmers and/or was characterized as a hard work, dependent on hand labor, and questionable regarding their viability depending on the size of the field area (SANTOS et al., 2013). Therefore, the accumulation of data on the improvement of this farming practice may be of great importance for small cotton farmers.

The objective of this study was to determine the spatial and temporal distribution of cotton squares and small cotton bolls fallen on the soil damaged by weevil as well as the efficiency of equipment to collect these plant structures.

\section{MATERIALS AND METHODS}

The study was conducted between 18 July and 23 October 2014 in the experimental field of Embrapa Cotton in Campina Grande, Paraiba, Brazil, covering an area of $180 \mathrm{~m}^{2}(12 \times 15 \mathrm{~m})$ that was historically infested by cotton boll weevil. The average temperature and relative humidity of the study area were $21.9^{\circ} \mathrm{C}$ and $82.4 \%$, respectively, during the study period.

\section{Cultivar}

We used the 'cultivar cotton BRS 8H', planted under dry land soil conditions classified as eutrophic Entisol, spaced $0.90 \mathrm{~m}$ between rows and $0.10 \mathrm{~m}$ between plants, leaving one plant per hole after thinning. At 35 days after germination (DAG), when the first cotton squares appeared, the experiments were initiated.

\section{Spatial and temporal distribution of fallen reproductive structures to the ground}

The spatial and temporal distribution of reproductive structures [cotton squares of large (6$8 \mathrm{~mm}$ diameter), medium (3-6mm diameter), and small bolls size $(5-8 \mathrm{~mm}$ diameter)] fallen on the soil damaged by boll weevil between cotton rows were determined in a randomized block design with a factorial arrangement of $4 \times 3$, represented by soil surface tracks located at $1-11 \mathrm{~cm}, 12-22 \mathrm{~cm}, 23-33 \mathrm{~cm}$, and $34-44 \mathrm{~cm}$ away from planting row on cotton plants at 70, 85, and 100 days of age.

Plots consisted of a soil surface strip between the rows of cotton crop measuring $0.9 \mathrm{~m} \times 3.0 \mathrm{~m}$, subdivided into eight smaller strips (four sub-strips located immediately after the first row of cotton and the other four immediately before the second row) of $0.1 \mathrm{~m}$ width, parallel to one another and located at different distances from the cotton row in treatments as described.

We quantified the distance, number, and percent of reproductive structures of cotton fallen on the ground with punctures of the feeding and/or oviposition by boll weevil by using soil strip every fortnight. Cotton squares and small cotton bolls fallen on the soil due to natural abscission were not considered in the data analysis.

\section{Equipment collection efficiency}

The efficiency of equipment to collect cotton squares and small cotton bolls fallen on the soil after damaged by boll weevil was determined in a design of randomized blocks with five treatments (10 repetitions each). Treatments consisted of the use of straight plastic rakes, a fan-shaped, big broom, collector instrument model CNPA, and leaves aspirator 'Trapp' (Trapp, Jaraguá do Sul, Santa Catarina, Brazil) to collect the aforementioned reproductive structures.

Collection operation using the big broom and plastic fan rakes and straight rakes included the step of sweeping the fallen reproductive structures on the ground between rows of cotton plantation and making a mound in the end of experimental street, followed by manual collection and packaging in cloth bags.

In the case of collector instrument model CNPA and of leave aspirator 'Trapp', the reproductive structures fallen on the soil were immediately collected by jamming of nails and vacuuming, respectively, followed by discharge in cloth bags 
for disposal. The study was conducted in the same area of the first experiment, taking advantage of the information generated to orientate the positioning of equipment for collection.

The evaluations were made every 2 weeks during the appearance of the first cotton squares until the formation of firm bolls, by counting the cotton squares and small bolls fallen on the soil before and after collection of these structures using the mentioned equipment. Number of cotton squares and small cotton bolls fallen on the soil due to the damage caused by boll weevil, the efficiency of collection, and the time spent in collecting these reproductive structures of the cotton plant were determined. Cotton squares and small cotton bolls fallen on the soil due to attack by other insect pests or by natural abscission of the cotton squares were not considered in the evaluation.

\section{Data analysis}

The data of spatial distribution and the time of collecting the cotton squares and small cotton bolls damaged by boll weevil and then fallen on the soil and the efficiency of collection equipment were subjected to analysis of variance and the means were compared by Tukey's test at 5\% probability using the System of Analysis Statistics and Genetics (SAEG) of the Universidade Federal de Viçosa.

\section{RESULTS AND DISCUSSION}

The abscission of cotton reproductive structures (squares and small bolls) can be attributed to several factors unrelated to pest infestations (GUINN, 1982; SHOWLER, 2008). In this study, most of the abscission of cotton squares and small bolls of the cultivar BRS $8 \mathrm{H}$ were due to physiological factors of the plant (51\%) followed by injury for oviposition of the boll weevil females $(42 \%)$. Abscission of reproductive structures by other unidentified factors was $7 \%$. There was no abscission of cotton squares and small bolls due to the attack of other insect pests. These results are similar to those obtained for natural abscission of reproductive structures in cotton (PEREIRA et al., 2004); however, it was higher than $27 \%$ of abscission attributed by the authors to adult boll weevil.

Among the abscissions due to boll weevil injuries, it was observed injuries due to other reasons amounted to $7 \%$ of total reasons. Squares and small bolls fallen on the soil had at least one puncture by oviposition, but the reproductive structures with only punctures of feeding remained attached to the plant. In addition, various bolls, especially large-sized ones $(>15 \mathrm{~mm}$ diameter) with punctures of feeding and oviposition produced cotton fibers. These results corroborated those obtained by SHOWLER et al. (2005) and SHOWLER (2008), confirming that the punctures by feeding in the cotton squares and small bolls are not associated with your abscission.

Spatial and temporal distribution of fallen reproductive structures to the ground

The distance means between cotton squares and small bolls fallen on the soil with punctures due to feeding and/or oviposition by boll weevil and the lap of cotton plant (cultivar BRS $8 \mathrm{H}$ ) did not differ with the age of the plant within the first $(1-11 \mathrm{~cm})$, second $(12-22 \mathrm{~cm})$, third $(23-33 \mathrm{~cm})$, and fourth $(34-44 \mathrm{~cm})$ strips of ground surface and were 7.51, 15.31, 27.65, and $37.74 \mathrm{~cm}$, respectively. Results indicated that the measured distance was not affected by phenological development of the cotton plant, probably because of the phenotypic characteristics of the canopy of the cotton cultivar BRS $8 \mathrm{H}$, which features cotton squares and positions of the flowering and fruiting, concentrated mostly around the main stem. Studies conducted with the cotton cultivars NuOpal, DeltaOpal FMT-701, FMX-910, and FMX-993 have revealed that the production and size of the fruit and its agronomic characteristics greatly depend on the location of the plant and the positions of the fruiting body both in the regions of vertical flowering and the regions of horizontal flowering, with more than $80 \%$ of the production defined at the regions of the bottom and middle-third of the cotton plant and at the first and second position of fruits (GRIGOLLI et al., 2013).

The amount of cotton squares and small bolls with punctures of feeding and/or oviposition by boll weevil and then fallen on soil in relation to the planting row showed significant relation with the plantage $\left(\mathrm{F}_{6: 33}=39.18, \mathrm{P}<0.001\right)$, indicating that the number of reproductive structures in each soil strip increased with the phenological development of the cotton plant (Table 1). The larger number of cotton squares and small bolls damaged by boll weevil fell within the range of $0.01 \mathrm{~m}$ to $0.11 \mathrm{~m}$ away from the planting row of plants of age 100 days. The smaller number of reproductive structures fell were $0.34 \mathrm{~m}$ to $0.44 \mathrm{~m}$ away from the planting row of plants of with 70 days, which corresponded to the strip of soil near the center of street between rows of cotton plant. In percent terms, the averages of cotton squares and small bolls damaged by boll weevil and then fallen on the ground at $0.01 \mathrm{~m}$ to $0.11 \mathrm{~m} ; 0.12 \mathrm{~m}$ to $0.22 \mathrm{~m} ; 0.23 \mathrm{~m}$ to $0.33 \mathrm{~m}$, and $0.34 \mathrm{~m}$ to $0.44 \mathrm{~m}$ distance throughout the study period were $49.57,35.63,11.54$, and $3.25 \%$, respectively (Table 1). These results can be attributed to the population growth of the boll weevil with overlapping generations synchronized with the phenological development of cotton 
Table 1 - Mean numbers \pm standard error (SE) and percent of cotton squares and small bolls of cultivar BRS 8h fallen on the soil after damage by boll weevil using distance strip (DS) on the soil surface in relation to row of cotton plants of different ages.

\begin{tabular}{|c|c|c|c|c|c|c|}
\hline \multirow[t]{3}{*}{ Trat } & 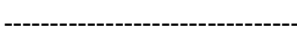 & & ----Plant age (days & & & \\
\hline & \multicolumn{2}{|c|}{-------------------------70-------------------------- } & \multicolumn{2}{|c|}{--------------------------85---------------------- } & \multicolumn{2}{|c|}{ 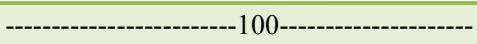 } \\
\hline & Mean numbers $\pm \mathrm{SE}$ & $(\%)$ & Mean numbers $\pm \mathrm{SE}$ & $(\%)$ & Mean numbers $\pm \mathrm{SE}$ & $(\%)$ \\
\hline DS1 & $42.75 \pm 02.87 a b^{1} C^{2}$ & 48.72 & $155.25 \pm 17.22 \mathrm{aB}$ & 53.21 & $216.25 \pm 11.91 \mathrm{aA}$ & 46.78 \\
\hline DS2 & $30.25 \pm 04.39 \mathrm{abc} \mathrm{C}$ & 34.47 & $99.75 \pm 04.80 \mathrm{bB}$ & 34.19 & $176.75 \pm 06.64 \mathrm{bA}$ & 38.24 \\
\hline DS3 & $12.00 \pm 02.27 \mathrm{bc} \mathrm{B}$ & 13.68 & $27.50 \pm 05.42 \mathrm{cB}$ & 09.43 & $53.25 \pm 05.45 \mathrm{cA}$ & 11.52 \\
\hline DS4 & $02.75 \pm 00.48$ c A & 03.13 & $09.25 \pm 01.31 \mathrm{cA}$ & 03.17 & $16.00 \pm 02.27 \mathrm{dA}$ & 03.46 \\
\hline$\Sigma$ & 87.75 & 100.00 & 291.75 & 100.00 & 462.25 & 100.00 \\
\hline
\end{tabular}

Treat. $($ Treatments $)=(D S 1)$ from 1 to $11 \mathrm{~cm}$; (DS2) from 12 to $22 \mathrm{~cm}$; (DS3) from 23 to $33 \mathrm{~cm}$ (DS4) from 34 to $44 \mathrm{~cm} .{ }^{(1)}$ Means followed by the same letter in the column are not different by Tukey test $(\mathrm{P}<0.05) .{ }^{(2)}$ Means followed by the same capital letter in the line are not different by Tukey test $(\mathrm{P}<0.05)$.

with increased formation of cotton squares and bolls (SHOWLER et al., 2005).

Irrespective of the cotton plant age, more number of cotton squares and small bolls with punctures of feeding and/or oviposition by boll weevil fell near the lap of the plant at a distance of $0.01 \mathrm{~m}$ to $0.11 \mathrm{~m}$ away from the planting row, followed by the distance of $0.12 \mathrm{~m}$ to $0.22 \mathrm{~m}$ away from the planting row (Table 1). Greater numbers of cotton squares on the soil surface strips near the plant's lap corresponds to the first, second, and third position of the fruitful or sympodial branch until the sixth node of main axis, where most of these reproductive structures are located (GRIGOLLI et al., 2013). Therefore, if we considered one distance of the soil surface from the planting row until $0.22 \mathrm{~m}$, the percent of reproductive structures fallen on the soil with punctures of feeding and/or oviposition by boll weevil was $85.20 \%$, which corresponded to the percent projection of cotton canopy of the cultivar BRS $8 \mathrm{H}$. This result was $>70 \%$ of cotton squares fallen on the soil at a distance of $0.25 \mathrm{~m}$ from the planting row observed by SMITH (1977), which can be attributed to the differences in the methodology applied and the cultivars and cultivation practices used as well as the climatic conditions (GUINN, 1982).

\section{Equipment collection efficiency}

Significant interaction observed between equipment and age of the culture for collection efficiency $\left(\mathrm{F}_{8: 42}=2.71, \mathrm{P}<0.02\right)$ of the fallen reproductive structures on soil damaged by boll weevil indicated that the efficiency to collect them was affected by the type of equipment used in a certain age of cotton plant (Table 2). This can be attributed to less efficient sweeping of cotton squares and small bolls fallen on the ground by using big broom between rows of cotton plants aged 85 days because rainfall occurred 5 days prior to the experiment. Rainfall probably increased the moisture of soil and cotton squares and small bolls fallen on the soil, which consequently increased the weight and grip of these structures on the soil surface, reducing the sweep and efficient relocation and collection processes (SMITH, 1977). Collection efficiency was only little affected by rainfall.

The collection efficiencies of cotton squares and small bolls fallen on the soil between the cotton rows using plastic fan rakes and straight rakes, big broom (collector instrument CNPA model), and aspirator of the leaves 'Trapp' ranged from $76 \%$ to $88 \%$ for all plants despite their age (Table 2). Results are similar to the variations in the collection efficiency of the cotton squares fallen on the ground from $69 \%$ to $89.2 \%$ by manual collection and by using collector instrument CNPA model, big broom, and metal broom in cotton crops of the municipality of Sousa, Paraíba, Brazil (BELTRÃO et al., 1997). Conversely, it was higher than the collection efficiency variations from $59 \%$ to $74.2 \%$ observed by the authors in the study with cotton in Palmas de Monte Alto, Bahia, Brazil using the hands and collection equipment (same as in this study), and, also, the collection efficiency variations of $49.7 \%$ to $69.1 \%$ obtained by a flail-type suction machine mounted on the tractor in experimental area with cotton crops in Columbia, Missouri, United States (SMITH, 1977).

The time required to collect the reproductive structures damaged by boll weevil and then fallen on the soil between the cotton plant rows showed a significant interaction between age and culture equipment $\left(\mathrm{F}_{8: 42}=3.44, \mathrm{P}<0.01\right)$ (Table 2$)$, indicating that the time taken to collect them was affected by the type equipment in a certain age of the plant. The greatest time spent for the collection of these

Ciência Rural, v.47, n.7, 2017. 
Table 2 - Mean \pm standard error (SE) of efficiency and time interval required to collect cotton squares and small bolls fallen on the soil damaged by boll weevil between rows of different ages.

\begin{tabular}{|c|c|c|c|}
\hline \multirow{3}{*}{ Treat } & \multicolumn{3}{|c|}{ 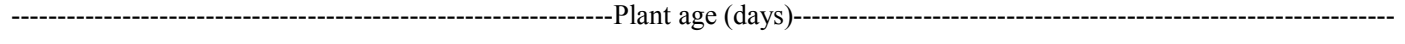 } \\
\hline & 70 & 85 & 100 \\
\hline & \multicolumn{3}{|c|}{ 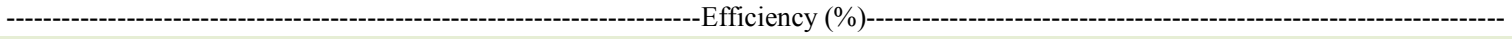 } \\
\hline 01 & (1) $76.05 \pm 2.65$ a B & $79.15 \pm 3.01 \mathrm{ab} \mathrm{AB}$ & $93.45 \pm 0.87 \mathrm{a} \mathrm{AB}$ \\
\hline 02 & $80.65 \pm 1.65$ a A & $81.10 \pm 3.32 \mathrm{ab} A$ & $90.12 \pm 1.33$ a A \\
\hline 03 & $88.50 \pm 1.39$ a A & $62.95 \pm 4.21 \mathrm{~b} \mathrm{~B}$ & $92.82 \pm 1.53$ a A \\
\hline 04 & $80.15 \pm 4.30 \mathrm{a} \mathrm{A}$ & $66.10 \pm 4.37 \mathrm{ab} \mathrm{A}$ & $76.50 \pm 5.56$ a A \\
\hline 05 & $77.68 \pm 1.29 \mathrm{a} \mathrm{A}$ & $84.25 \pm 1.08 \mathrm{ab} \mathrm{A}$ & $78.50 \pm 2.65$ a A \\
\hline \multicolumn{4}{|c|}{--- } \\
\hline 01 & ${ }^{(2)} 1.90 \pm 3.59 \mathrm{ab} \mathrm{B}$ & $1.78 \pm 1.05 \mathrm{ab} \mathrm{B}$ & $2.46 \pm 0.10 \mathrm{ab} \mathrm{A}$ \\
\hline 02 & $1.80 \pm 0.01 \mathrm{ab} \mathrm{A}$ & $1.83 \pm 0.12 \mathrm{ab} B$ & $2.43 \pm 0.18 \mathrm{ab} \mathrm{A}$ \\
\hline 03 & $1.45 \pm 0.04 \mathrm{~b} \mathrm{~B}$ & $1.55 \pm 0.06 \mathrm{abc} \mathrm{A}$ & $1.66 \pm 0.02 \mathrm{c} \mathrm{A}$ \\
\hline 04 & $0.80 \pm 0.04 \mathrm{c} \mathrm{B}$ & $1.33 \pm 0.04 \mathrm{bc} \mathrm{B}$ & $2.15 \pm 0.17 \mathrm{abc} \mathrm{A}$ \\
\hline 05 & $1.90 \pm 3.59 \mathrm{ab} B$ & $1.13 \pm 0.03 \mathrm{c} \mathrm{B}$ & $1.87 \pm 0.17 \mathrm{bc} \mathrm{A}$ \\
\hline \multicolumn{4}{|c|}{ - } \\
\hline & 3.7 & 58.3 & 3.5 \\
\hline
\end{tabular}

Treat. $($ Treatments $)=(01)$ fan-like rake; (02) straight rake; (03) big broom; (04) collector instrument model CNPA, and (05) leaves aspirator 'Trapp'. ${ }^{(1)}$ Mean of equipment efficiency followed by the same letter minuscule in column and same capital letter in line are not different by Tukey's test $(\mathrm{P}<0.05) .{ }^{(2)}$ Mean of collection time followed by the same letter minuscule in column and same capital letter in line are no1 different by Tukey's test $(\mathrm{P}<0.05) .{ }^{(3)}$ Cumulative precipitation 7 days before the test.

reproductive structures between cotton rows were observed with rakes (fan and rectum) for plants aged 100 days and lowest with aspirator 'Trapp' between cotton rows aged 70 days. These larger collection times with rakes was also recorded by BELTRÃO et al. (1997) and can be attributed to the greater effort by the operator to manually collect cotton squares and small bolls piled up at the end of the street, because of the increased amount of these reproductive structures at 70-100 days after emergence.

Our results showed that the collection of cotton squares and small bolls fallen on the soil must be performed with greater attention to the soil strips located below the cotton canopy projection and that the aspirator 'Trapp' was more suitable for this operation as it spent less time in collecting these reproductive structures, albeit with similar efficiency to other equipment.

\section{CONCLUSION}

The distance between the cotton squares and small bolls fallen on the soil after infestation with boll weevil until planting row did not differ with the age of the plant within each strip of the soil surface. However, the number of cotton squares and small bolls fallen on the soil differ with the distance and the age of the plants, with the highest number of these reproductive structures fallen on strips of soil next to the rows of older cotton plants.
All tested equipment showed similar collection efficiency for cotton squares and small bolls damaged by boll weevil that has fallen on the soil. However, the greatest time of collection of cotton squares and small bolls on the soil were spent using rakes (fan and rectum) at 100 days of plant age, while the least time was spend with aspirator 'Trapp' at 70 days of plant age.

\section{ACKNOWLEDGMENTS}

To Conselho Nacional de Desenvolvimento Científico e Tecnológico $(\mathrm{CNPq})$ and Coordenação de Aperfeiçoamento de Pessoal de Nível Superior (Capes) for financial support. Global Edico Services corrected and edited the English in this manuscript.

\section{REFERENCES}

BELTRÃO, N.E.M. et al. Desenvolvimento e avaliação de um catador de botões florais atacados pelo bicudo e caídos no solo. Campina Grande: Embrapa Algodão, 1997. 7p. (Pesquisa em Andamento, 37).

BURT, E.C. et al. Control of the boll weevil by mechanically destroying fallen infested cotton squares. Journal of Economic Entomology, v.62, p.862-865, 1969.

COAD, B.R.; McGEHEE, T.F. Collection of weevils and infested squares as a means of control of the cotton boll weevil in the Misssissippi Delta. Washington: U.S. Department of Agriculture 1917. 51p. (Bulletin, 564). Available from: <http://dx.doi. org/10.5962/bhl.title.64494>. Accessed: Oct. 10, 2016. 
GREENBERG S.M. et al. Insect population trends in different tillage systems of cotton in South Texas. Subtropical Plant Science, v.62, p.1-17, 2010. Available from: <https:/www.researchgate.net/ publication/44922345_Insect_Population_Trends_in_Different_Tillage Systems_of_Cotton_in_South_Texas $>$.Accessed: Nov. 15, $201 \overline{6}$.

GRIGOLLI, J.F.J. et al. Within plant distribution of Anthonomusgrandis (Coleoptera: Curculionidae) feeding and oviposition damages in cotton cultivars. Ciência e Agrotecnologia, v.36, p.78-84, 2013. Available from: $<$ http://www.scielo.br/scielo.php?script=sci_arttext $>$. Accessed: Dec. 20, 2015. doi: 10.1590/S1413-70542013000100009.

GUINN, G. Causes of square and boll shedding in cotton. Washington: U.S. Department of Agriculture Technical, 1982. 21p. (Bulletin, 1972).

NEVES, R.C.S. et al. Rational practices to manage boll weevils colonization and population growth on family farms in the Semiárido region of Brazil. Insects, v.5, p.818-831, 2014. Available from: $<$ http:// www.mdpi.com/journal/insects/>. Accessed: Mar. 21, 2016. doi: 10.3390/insects5040 818 .

NEVES, R.C.S. et al. Reducing boll weevil populations by clipping terminal buds and removing abscised fruiting bodies. Entomologia Experimentalis et Applicata, v.146, p.276-285, 2013. Available from: <http://www-periodicos-capes-gov-br.ez103.periodicos.capes. gov.br/index.php?>. Accessed: Apr. 18, 2016. doi: 10.1111/eea.12026.

PEREIRA, F.F. et al. Causas de abscisão e destruição de estruturas reprodutivas de plantas de algodoeiro. Revista Brasileira de Oleaginosas e Fibrosas, v.8, p.779-784, 2004.

RIBEIRO, E.B. et al. Métodos de destruição de restos de cultura do algodoeiro e sobrevivência do bicudo. Pesquisa Agropecuária Brasileira, v.50, p.993-998, 2015. Available from: http://seer.sct. embrapa.br/index.php/pab/article/view/21649/13112>. Accessed: Feb. 20, 2016. doi: 10.1590/S0100-204X2015001100001.
SALVADOR, R. et al. Transcriptomic survey of the midgut of Anthonomus grandis (Coleoptera: Curculionidae). Journal of Insect Science, v.14, p.1-9, 2014. Available from: <http://jinsectscience.oxfordjournals.org/>. Accessed: May 10, 2016. doi: 10.1093/jisesa/ieu081.

SANTOS, R.L. et al. Parasitoides do bicudo Anthonomus grandis e predadores residentes em algodoeiro pulverizado com caulim. Semina: Ciências Agrárias, v.34, p.3463-3474, 2013. Available from: <http://www.uel.br/revistas/uel/index.php/ semagrarias/article/view/12795>. Accessed: Feb. 21, 2016. doi: 10.5433/1679-0359.2013v34n6Sup11p3463.

SHOWLER, A.T. et al. Effects of planting dates on boll weevils (Coleoptera: Curculionidae) and cotton fruit in the subtropics. Journal of Economic Entomology, v.98, p.796-804, 2005.

SHOWLER, A.T. Relationships of abscised cotton fruit to boll weevil (Coleoptera: Curculionidae) feeding, oviposition, and development. Journal of Economic Entomology, v.101, p.68-73, 2008.

SILVA, A.L.A. de L.; SILVA, C.A.D. Determinação da concentração de caulim eficiente e econômica para a proteção de algodoeiro contra o bicudo. Pesquisa Agropecuária Brasileira, v.50, p.763-768, 2015. Available from: <http://seer.sct.embrapa.br/ index.php/pab/ article/view/21080>. Accessed: Feb. 23, 2016. doi: 10.1590/S0100204X2015000900004.

SILVA, C.A.D.; RAMALHO, F.S. Kaolin spraying protects cotton plants against damages by boll weevil Anthonomus grandis Boheman (Coleoptera: Curculionidae). Journal of Pest Science, v.86, p.563-569, 2013. Available from: <http://link.springer.com/ art icle/10.1007\%2Fs10340-013-0483-0>. Accessed: Jan. 16, 2016. doi: $10.1007 / \mathrm{s} 10340-013-0483-0$.

SMITH, D.B. Equipment for capturing fallen cotton squares. Washington: U.S. Department of Agriculture, 1977. 11p. (Bulletin, 1561). 